
Word Count (Without References):
9,411 words
Word Count (Including References):
11,731 words

\title{
Landscapes of Internment: British Prisoner of War Camps and the Memory of the First $\underline{\text { World War }}$
}

In March 2016, the Lord Lieutenant of Cheshire, David Briggs, dedicated a new war memorial in the town of Handforth, which lies just north of Wilmslow and some 16 kilometers south of Manchester. It may have been over 100 years since the outbreak of the First World War and more than 70 years since the end of the Second World War, but temporal distance did little to dampen local enthusiasm for the memorial. Schoolchildren, war veterans, and local councilors gathered to watch the Lord Lieutenant officially unveil the memorial and to hear the British national anthem ring out at the culmination of the ceremony. The light stone structure itself contains the names of 26 soldiers from the First World War, ten from the Second and one from the more recent Afghanistan conflict. As is typical of many British memorials, none of the war dead had actually died in Handforth; instead they had lost their lives either on the battlefield or in hospitals behind the lines. ${ }^{1}$

What was far more unusual about this new memorial, however, was the fact that a further 19 soldiers had actually died in Handforth during the First World War. Yet, the names of these men were left off the finished memorial. This was no oversight. Presumably, the reason for their absence is that these men had all been German prisoners of war (POWs) held in the Handforth internment camp. During the First World War, over 115,000 civilian and military

\footnotetext{
1 "Memorial Honours War Fallen," Wilmslow Guardian, 30 March 2016, 12; Alex King, Memorials of the Great War in Britain: the Symbolism and Politics of Remembrance (Oxford, 1998), 237.
} 
prisoners were interned in some 12 major camps and many smaller facilities scattered across Britain. This article focuses on three of the largest camps established in mainland Britain: Handforth in East Cheshire, Frith Hill, near Frimley, Surrey, and Dorchester in Dorset. ${ }^{2}$ Not only does this selection allow for geographical spread, but it also brings together three camps of a comparable size that operated, albeit with short breaks in the case of Frith Hill, from 1914 through to $1919 .{ }^{3}$ Despite each camp housing up to 4,000 prisoners at any one time, there are very few traces of this episode in any of the three towns today. ${ }^{4}$ Indeed, in the case of Handforth, the erection of the new war memorial almost completely obscured a complex history of internment in favor of a more familiar narrative of honoring those "who made the ultimate sacrifice." 5

This article considers the process by which these enormous camps, which had so dominated their surroundings, disappeared from local and national memory cultures. The key to uncovering this process, the article contends, lies in the landscape. As W. J. T. Mitchell and Simon Schama have long made clear, trees, rivers, forests, and fields play a crucial role in the formation of "social and subjective identities." ${ }^{6}$ When internment camps opened during the First World War, these places disrupted local people's existing relationship to their surroundings, challenging their sense of being part of an unchanged "enduring landscape."7 Not only did the erection of barbed wire and watchtowers create new "militarized landscapes," but the camps themselves also placed the enemy directly into what had hitherto been a British

\footnotetext{
${ }^{2}$ Only Dorchester has been the subject of a short, local history: Brian Bates, Living with the Enemy: Dorchester's Great War Prison Camp (Frampton, 2015).

${ }^{3}$ The choice of three similarly sized camps allows for a practical comparative framework: William Sewell, "Marc Bloch and the Logic of Comparative History," History and Theory 6, no. 2 (1967): 208-18.

${ }^{4}$ Aside from those on the Isle of Man, it was only the camps in Stobs, Eastcote / Pattishall, Frimley, and Dorchester that had equitable or larger populations for the period 1914-1919: Panikos Panayi, Prisoners of Britain: German Civilians and Combatant Internees during the First World War (Manchester, 2012), 44, 88-9.

5 "Memorial to Honour our Fallen Unveiled," Wilmslow Guardian, 30 March 2016, 1.

${ }^{6}$ W. J. T. Mitchell, "Introduction," in Landscape and Power, ed. W. J. T. Mitchell (Chicago, 1994), 1-4, at 1; Simon Schama, Landscape and Memory (London, 1995).

7 David Lowenthal, "British National Identity and the English Landscape," Rural History, 2, no. 2 (October 1991): 205-30, at 217.
} 
environment. ${ }^{8}$ As the article makes clear, the camps were never sealed off entirely from their surroundings. Around each camp, a more fluid zone developed, where the military world of guards and POWs brushed up against the local population. With both civilians and the prisoners forced to share the same militarized environment, tensions frequently occurred over everything from access to resources through to the disposal of refuse and sewage.

Despite the deep entanglements between the camps and their civilian surroundings, historical writing very rarely views wartime internment as part of a militarized landscape. Indeed, the studies that have followed in the footsteps of David Cesarani and Tony Kushner's pioneering work from the early 1990s have largely ended at the gates of the camps. ${ }^{9}$ A narrow focus on the supposedly self-contained camp world is clear from explorations of the prisoners' cultural activities. Based on the notion that confinement also provided some degree of cultural freedom, a vast body of historical writing has sought to explore everything from camp newspapers through to art and photographs. ${ }^{10}$ Taking this approach a stage further, Brian Feltman views the POW' theatre productions and musical activities as a sign of resistance; Alon Rachamimov, meanwhile, argues that such performances highlighted shifting masculine identities. ${ }^{11}$ While these studies shed light on everyday life in the camps, they reveal far less about the world beyond the wire.

\footnotetext{
${ }^{8}$ On the term "militarized environments," see: Chris Pearson, Mobilizing Nature: The Environmental History of War and Militarization in Modern France (Manchester, 2012). Other important work in the field prefers the slightly narrower term "militarized landscapes": Militarized Landscapes: From Gettysburg to Salisbury Plain, ed. Chris Pearson, Peter Coates and Tim Cole (London, 2010); Marianna Dudley, An Environmental History of the UK Defence Estate, 1945 to the Present (London, 2012).

${ }^{9}$ The Internment of Aliens in Twentieth Century Britain, ed. David Cesarani and Tony Kushner (London, 1993). See also "Totally Un-English"? Britain's Interment of "Enemy Aliens" in Two World Wars, ed. Richard Dove (Amsterdam, 2005). For a variety of national perspectives, see: Kriegsgefangene im Europa des Ersten Weltkriegs, ed. Jochen Oltmer (Paderborn, 2006).

${ }^{10}$ Cultural Heritage and Prisoners of War: Creativity behind Barbed Wire, ed. Gilly Carr and Harold Mytum (New York, 2012).

${ }^{11}$ Brian Feltman, The Stigma of Surrender: German Prisoners, British Captors, and Manhood in the Great War and Beyond (Chapel Hill, 2015), 106-7; Alon Rachamimov, "The Disruptive Comforts of Drag: (Trans)Gender Performances among Prisoners of War in Russia, 1914-1920," American Historical Review, 111, no. 2 (April 2006): 362-82, at 364; Mahon Murphy, Colonial Captivity during the First World War: Internment and the Fall of the German Empire, 1914-1919 (Cambridge, 2017).
} 
Other areas of the existing historiography are also spatially restricted. The treatment of enemy soldiers at the moment of capture, which forms another significant research strand, certainly extends beyond the camp boundaries, but only really to consider incidences of violence once soldiers were in enemy hands. ${ }^{12}$ Oliver Wilkinson's comprehensive exploration of British POWs in German captivity is a case in point. In one detailed chapter, Wilkinson considers the psychological impact of surrender, particularly when soldiers were disarmed and often robbed of their possessions. But any interactions beyond the closed world of the individual are left largely unsaid. ${ }^{13}$ Work on civilian internees might have offered more scope for exploring civilian-military entanglements, but here too the focus has tended to be largely confined to life in the camps themselves, rather than the world beyond the wire. ${ }^{14}$ Both Matthew Stibbe and Panikos Panayi, for example, who have examined British and German civilians interned in Germany and Britain respectively, have concentrated principally on the camp system and its impact on those who were unfortunate enough to be held within its grasp. ${ }^{15}$

By instead situating the wartime internment camps within a wider militarized environment, the absence of these facilities from Britain's memory culture becomes much clearer. At first, local residents generally tolerated the camps, particularly as they allowed for a satisfactory glance at a vanquished enemy. However, neither the War Office nor the existing population had a real understanding of how these new places fitted into the landscape. As a result, it gradually became clear that the camps themselves also intruded into, and even

\footnotetext{
${ }^{12}$ Uta Hinz, Gefangen im Großen Krieg: Kriegsgefangenschaft in Deutschland, 1914-1921 (Essen, 2006), 185203; Heather Jones, Violence against Prisoners of War in the First World War: Britain, France and Germany, 1914-1920 (Cambridge, 2011), 33-69.

${ }^{13}$ Oliver Wilkinson, British Prisoners of War in First World War Germany (Cambridge, 2017), 23-42.

${ }^{14}$ Stefan Manz, "Enemy aliens" in Scotland in a Global Context, 1914-1919: Germanophobia, Internment, Forgetting," in Minorities and the First World War: From War to Peace, ed. Tim Grady and Hannah Ewence (Basingstoke, 2017), 117-42.

${ }^{15}$ Matthew Stibbe, British Civilian Internees in Germany: The Ruhleben Camp, 1914-1918 (Manchester, 2008); Panayi, Prisoners.
} 
damaged, people's existing sense of place. ${ }^{16}$ The noise and smells of the prisoners flowed into the neighboring communities, even the streets became more threatening whenever the POWs used them for exercise. It was only when the British started to employ POWs to work the land that some of these tensions started to fade. With the end of hostilities, the local population was only too keen for the camps to close, the environment to be demilitarized and their previous bonds to the landscape to be restored. There was, therefore, never a sentimental attachment to these sites of internment, which in other circumstances could have led to calls for their preservation. These were places that people were content to see fade, rather than to become permanent British "sites of memory."17

\section{I - Arrivals}

At the start of the conflict, the residents of Dorchester, Frimley, and Handforth had every reason to believe that their towns were likely to make a considerable military contribution. The army already had a significant presence in both Frimley and Dorchester. The Surrey heathland bordering Frimley had long been home to training camps, while the Royal Military College, Sandhurst lay a mere four kilometers further north. Dorchester had a similar military pedigree. The town was not only home to the Dorsetshire Regiment, but had also once housed a battery of the Royal Horse Artillery. Handforth, in contrast, had no previous military associations, but this soon changed with the outbreak of hostilities. In August 1914, plans were immediately developed to house a battalion of the Manchester Regiment in a disused textiles factory that lay just south of the village center. Handforth's local newspaper, The Alderley and Wilmslow

\footnotetext{
${ }^{16}$ Leif Jerram, "Space: A Useless Category for Historical Analysis?," History and Theory, 52, no. 3 (October 2013): 400-419.

17 This was the case with many Second World War American airbases in Britain which have been preserved as heritage assets: Sam Edwards, "Ruins, Relics and Restoration: The Afterlife of World War Two American Airfields in England, 1945-2005," in Militarized Landscapes: From Gettysburg to Salisbury Plain, ed. Chris Pearson, Peter Coates and Tim Cole (London, 2010), 209-28; Pierre Nora, Les Lieux de Mémoire (Paris, 1984. 1992).
} 
Advertiser, welcomed this development, confirming that the factory was "plenty large enough" to accommodate 2,000 men. $^{18}$

However, once Britain was fully at war, the military authorities quickly realized that they not only required facilities for the fighting troops, but also for the captured enemy. After only a matter of weeks, large numbers of Germans, Austrians, and Hungarians had already fallen into British hands. At first, "enemy aliens," which was a catch-all term for civilians living in Britain, formed the largest contingent of prisoners. They were arrested and interned on an ad hoc basis from August 1914, until finally in May 1915 the government announced the detention of all male "enemy aliens." Soldiers captured in the fighting at the front formed a second, initially much smaller, group, though one that grew exponentially as the conflict dragged on. ${ }^{19}$

Faced with a sudden need to intern thousands of people, the War Office scrambled around frantically for a solution. The Royal Horse Artillery barracks in Dorchester, which at this time were empty, provided one immediate answer. During early August, the existing barracks were adapted for prisoners, with space set aside for further accommodation blocks if required. ${ }^{20}$ Frimley was also an early candidate for prisoners. The open heathland that bordered the town, which had long been used for military maneuvers, again seemed ideal for enemy internment. Within the first weeks of the war, huts and tents started to be erected on open land, known as Frith Hill. ${ }^{21}$ Handforth, the site of the third camp, was chosen more by chance. In September, the War Office had asked for information of sites across the country that could be used for internment purposes. The local Urban District Council did its best to ignore the War Office's advances, claiming that there was "no place" within Handforth "that would be

\footnotetext{
18 "Handforth A Military Centre?," The Alderley and Wilmslow Advertiser, 18 September 1914, 5.

${ }^{19}$ Panayi, Prisoners, 47-51.

20 "War Prison at Dorchester," The Western Morning News, 8 August 1914, 8.

21 "The War. How is it Affecting the Camberley District," Camberley News and Yorktown Observer, 15 August $1914,3$.
} 
suitable." ${ }^{22}$ But in the end, it was hard to dispute that the large factory site, which had been earmarked for the Manchester Regiment, would also be suitable for prisoners. Once the decision had been made, the military made some rudimentary repairs to the empty factory, "rapidly transforming the interior of the buildings into habitable quarters." 23

Constructing the internment camps always involved much more than the simple provision of beds or eating facilities. In all three cases, the surrounding landscape also had to be reconfigured and militarized. The most visible change in this respect came with the introduction of containment measures. Each camp was provided with a secure barbed wire fence. In the case of Dorchester, a series of wooden guard towers that interspersed the fence added a further layer of protection. ${ }^{24}$ The open heathland of Surrey was also fenced off with "a thick entanglement of barbed wire," which according to some reports contained "a powerful electric current at high voltage." 25 The enclosures surrounding the camps were as much about keeping the local population out, as the prisoners in. Indeed, the military declared the land around the Frith Hill camp a "forbidden zone," with anybody coming too close threatened with arrest. ${ }^{26}$ For the local population, therefore, a once familiar landscape had suddenly been placed off-limits.

The erection of internment camps, which would have been unfamiliar and unimaginable places for the local populations, certainly altered their relationship to the existing landscape. However, with the war ongoing, they were powerless to object in any meaningful way. Unable to control the local environment physically, the British public instead sought to maintain a symbolic presence. In this struggle for space, language, clothing, and flags became the weapons

\footnotetext{
${ }^{22}$ Reginald Potts, 16 September 1914 and Handforth Urban District Council to Reginald Potts, 18 September 1914, CCJ11/29, Cheshire Record Office (henceforth CRO).

23 "German Prisoners in Camp at Handforth," The Alderley and Wilmslow Advertiser, 9 October 1914, 8.

${ }^{24}$ Bruno Schmidt-Reder, In England Kriegsgefangen! Meine Erlebnisse in dem Gefangenenlager Dorchester (Berlin, 1915), 35.

25 "Electric Shocks for Prisoners," Coventry Evening Telegraph, 29 August 1914, 3.

26 “Camp Visitor's Arrest," Buckingham Advertiser and Free Press, 24 October 1914, 8.
} 
of choice. ${ }^{27}$ The setting for these symbolic clashes was the streets. Knowing that every prisoner entering or leaving a camp would have to make the slow passage along the open streets, local people often stood ready to "welcome" their defeated enemy.

The moment of arrival was when the prisoners tended to be at their weakest. After stepping off the train in Frimley, George Kenner, a German businessman who had been living in London, recalled: "we marched into uncertainty." 28 Many of the civilian prisoners, like Kenner, had gone from having homes, jobs and families to being confined in strange surroundings. Others had been forced to undertake long, arduous journeys into captivity. Gotthilf Vöhringer, a Protestant missionary who had been serving in Cameroon, for example, was captured by the British and sent to Lagos in Nigeria, from where he was shipped to Southampton. After a brief break on the south coast, he was then placed on a train to the Handforth camp, arriving several weeks after his initial capture "hungry and chilled to the bone." 29 If the strains of capture were bad enough for "enemy aliens," then this was even more the case for military prisoners. Not only did the POWs have to cope with a disorientating journey to the camps, but many also arrived battle-weary and wounded. What struck one journalist about "the Huns" disembarking in Frimley was their "bedraggled, untidy and unkempt appearance"; many of the men were "without hats" and their uniforms were "faded and of much worn appearance." ${ }^{30}$

For military prisoners, the journey to the camps could be even more disconcerting. Soldiers, who had been taken from the heat of battle, tired, exhausted and sometimes even nursing wounds, arrived in Dorchester, Frimley and Handforth often to find a crowd of British

\footnotetext{
${ }^{27}$ For thoughtful reflections on the occupation of contested urban spaces, see: Nadine Rossol, Performing the Nation in Interwar Germany: Sport, Spectacle and Political Symbolism, 1926-36 (Basingstoke, 2010), 13-33.

${ }^{28}$ George Kenner, "Sketches of a German Interned Civilian Prisoner in England," 1929. Available: https://www.flickr.com/photos/20783398@N05/albums/72157643374512873/with/2027078162/

${ }^{29}$ G. Vöhringer, Meine Erlebnisse während des Krieges in Kamerun und in englischer Kriegsgefangenschaft (Hamburg, 1915), 19.

30 "German Prisoners Arrive," Camberley News and Yorktown Observer, 9 October 1915, 3.
} 
civilians waiting to "greet" them. In all three towns, news that a contingent of prisoners was on their way led people to gather on the streets hoping to catch a glimpse. The crowds, particularly in the early months of the war, could number into the hundreds. In Frimley, people "waited for several hours" outside the town's railway station, not to catch a train, but to see the Germans arriving. ${ }^{31}$ In Handforth, meanwhile, the police even had to intervene "with the object of dispersing the people" as the road from the station had become "so crowded," while in Dorchester an "enormous" crowd also led to enforced road closures. ${ }^{32}$ This was an occurrence not unique to these regions. Across Britain people flocked to see the new arrivals and in Germany too the public also travelled to internment camps hoping to get a glimpse of their enemy behind wire. ${ }^{33}$

Indeed, the geographical location of the Frith Hill and Handforth camps - a short journey from London and Manchester respectively - made them particularly susceptible to spectators. On weekends, "holiday-makers," as the Manchester Evening News termed them, often travelled down to Handforth "in the hope of catching a glimpse" of the Germans. ${ }^{34}$ In both regions, spotting the prisoners became something of a spectator sport. One young Mancunian couple had planned to spend the day at the city's Belle Vue Zoo, but in the end decided to join the crowds at the internment camp instead. "Caged men at Handforth sounded more novel and exciting than caged animals," reported the Liverpool Echo. ${ }^{35}$ In Frith Hill, the arrival of the Germans apparently caused greater excitement than the annual Royal Ascot horse race, with more traffic and greater numbers of pedestrians. ${ }^{36}$

\footnotetext{
31 "German Prisoners at Frimley," Surrey Advertiser, 26 September 1914, 3.

32 "More Prisoners at Handforth," The Alderley and Wilmslow Advertiser, 13 November 1914, 6; "The Prisoners of War," Camberley News and Yorktown Observer, 27 August 1914, 6.

${ }^{33}$ Jones, Violence, 49-50; Hinz, Kriegsgefangenschaft, 188-9.

34 “German Prisoners at Handforth," Manchester Evening News, 2 August 1915, 3.

35 “Teutonic Humour," Liverpool Echo, 9 February 1915, 4.

36 “German Prisoners Camp," Surrey Advertiser, 30 September 1914, 2.
} 


\section{[Image 1 here]}

Evidence of tourism to the camps has added to the impression that the British public travelled to view the internment camps solely out of "curiosity." 37 There was, however, always another motivation at play. The "curious" crowds often utilized the open space of the street to demonstrate their own position of power against their vanquished foe. One British press photographer captured these interactions as a group of some 600 men, reportedly fresh from the fighting at Neuve Chapelle, arrived in Handforth (see Image 1). The tightly packed group of German POWs marched four to five abreast down to the camp, while armed soldiers and policemen guarded the route. The men looked to be in good physical shape, a few even smiled and joked to their neighbors; others, particularly those on the far left of the picture, looked nervously around, seemingly surveying an unfamiliar landscape. Lest they become too comfortable in their new surroundings, British civilians held back by a policeman can be seen on one side of the street, while on the other some young men casually looked on from a farm gate, very much at ease in their surroundings.

The contrast between the bedraggled soldiers in their dirty uniforms and the smartly dressed civilians, including two women wearing fine hats, highlights the power dynamics at play. The image itself reveals no sign of any verbal exchange between the British and Germans. Earlier reports from Handforth, though, suggest that shouts and taunts towards the POWs were likely to have occurred. When the first civilian prisoners arrived in November 1914, for example, the waiting crowds had directed "good-natured badinage" at their new enemy. ${ }^{38}$ At the Frith Hill camp, people in the crowds had gone a stage further. One "well-dressed woman" stepped out of her car and began "frantically waving a Union Jack in the faces of the

\footnotetext{
${ }^{37}$ Jones, Violence, 49.

38 “German Prisoners Interned at Handforth,” The Alderley and Wilmslow Advertiser, 6 November 1914, 5.
} 
prisoners." 39 Such overt displays of nationalism may have been rare, but they did nonetheless reflect local people's attempts to stress their rightful position within the wider landscape.

\section{II - Smellscapes and Soundscapes}

Once the prisoners had arrived at their internment destination, their British captors placed them securely behind barbed wire. However, it became clear very quickly to all concerned that the boundaries of the camps were extremely fluid. As the local populations living in and around Dorchester, Frimley and Handforth discovered, the prisoners and the camps that housed them also had a major impact on the wider landscape. Most significantly, human waste from the camps seeped into neighboring fields and watercourses. By the summer of 1915, there were up to 3,500 internees in Dorchester, some 1,500 in Frith Hill and 2,100 in Handforth. ${ }^{40}$ With such large numbers of people confined to camps, the issue of sewage became an urgent and evergrowing problem.

Very little thought had been given to the question of waste disposal when the camps had been first established. In Handforth, the factory buildings, which formed the basis of the internment camp, had never been completely finished. As such, they lacked running water or a proper sewage system. Facilities were similarly provisional at Frith Hill, which consisted for the most part of temporary canvas tents erected on an open hillside. The government's official policy on the sanitation of internment camps allowed it to defray some of its wider responsibilities. Rather than being under sole jurisdiction of the military, issues of health and hygiene were placed into the hands of the local councils and more specifically the local medical officers of health. ${ }^{41}$ This approach was fine in principle, but in reality, far from adequate; not

\footnotetext{
39 "To the Editor," Camberley News and Yorktown Observer, 19 September 1914, 3.

${ }^{40}$ Graham Mark, Prisoners of War in British Hands during WWI ([Great Britain], 2007), 74, 92, 103.

${ }^{41}$ Foreign Office report, December 1914, FO383/106, The National Archives, Kew (henceforth TNA).
} 
only was the existing inspection regime ill-equipped to deal with the scale of the task, but the local medical officers of health were also slow to commence their work.

In their public pronouncements, however, the British military and the government firmly rejected any suggestions that the camp system was failing. When a Glasgow export firm contacted the Foreign Office about alleged rumors of poor sanitation, it received a robust response. The complainant was assured that there had been a mere five deaths in the camps all from "natural causes" - and that every effort was being made to ensure hygiene conditions were "as nearly perfect as possible." 42 The government also took a firm line on the issue in parliamentary debates. In response to a Liberal Party politician, who questioned standards in the Handforth camp, Harold Tennant, the Under-Secretary of State for War insisted that "military sanitary officers" had fully examined the camp and did not believe "insanitary conditions will arise." ${ }^{43}$ In private, though, the military was less optimistic, admitting that the sanitation facilities at Handforth, in particular, were recognized "as not being satisfactory." 44

The government may have been able to silence its distant critics in parliament or in business, but the British population living in and around the camps proved much harder to appease. What most aggrieved local people was not just that the camps existed, but the fact that these sites also started to change local landscapes. In all three areas, disposing of the prisoners' waste caused the greatest problems. With no connection to the mains sewage system, waste from the Frith Hill and Handforth camps had to be physically removed. Reverting to the nineteenth century model of human waste disposal, the Wilmslow and Frimley Urban District Councils regularly dumped sewage on open agricultural land where it could feed the soil. ${ }^{45}$

\footnotetext{
${ }^{42}$ Leisler, Greig \& Co to the Under Secretary for Foreign Affairs, 4 January 1915; Foreign Office to Leisler, Greig \& Co, 14 January 1915, FO383/106, TNA.

${ }^{43}$ Harold Tennant, House of Commons, Written Answers, 19 November 1914, Parliamentary Debates, vol. 68, cols. 565-6.

${ }^{44}$ War Office to Under-Secretary of State, Foreign Office, 15 January 1915, FO383/107, TNA.

${ }^{45}$ Wilmslow Urban District Council Committee Minutes, 25 January 1915, LUW/2472/3/4, CRO.
} 
It did not take long for the consequences of these decisions to be felt. In Frimley, effluent from the camp ran into a watercourse known as Jack's Pond and then flowed into neighboring ditches. ${ }^{46}$ Facing similar problems of environmental pollution in Handforth, one local landowner demanded an indemnity from the council. "Excreta," they complained, could potentially run off the fields, thereby leading to the "fouling of the River Dean." ${ }^{47}$ Far more intrusive for local people were the altered "smellscapes" around the camps. "W8 "Whenever the wind was blowing," explained an A. Smithson from the hamlet of Dean Row that lay south east of the Handforth camp, smells continually wafted into his house. Smithson was not alone in bemoaning such nasal intrusions. Eventually Cheshire's Chief Medical Officer stated that he was "so weary of receiving complaints" about smells that he would not defend the Urban District Councils if the matter went to court. At the same time in Frimley, the Council proposed covering the prisoners' waste with both soil and disinfectant to stop smells lingering. ${ }^{49}$

Dealing with the problem of sewage also had financial implications for the local councils. At the Handforth camp, the two neighboring councils - Wilmslow and Handforth took responsibility for waste disposal. They sent a regular stream of council carts to the camp to remove the growing piles of human waste and other refuse. All of this added a considerable financial burden to the two councils, particularly as the camp itself had initially been classed as a non-rateable property, which meant that the two councils received no regular payments from the War Office for their services.$^{50}$ Even in Dorchester, where the internment camp had a main sewage connection, financial and sanitation problems still occurred. Due to the "large numbers of German prisoners," the town's sewage works had had to "deal with an increased

\footnotetext{
46 "German Prisoners Arrive," Camberley News and Yorktown Observer, 8 May 1915, 3.

${ }^{47}$ Wilmslow Urban District Council Committee Minutes, 22 February 1915, LUW/2472/3/4, CRO.

${ }^{48}$ Mark Jenner, "Follow your Nose? Smell, Smelling, and their Histories," The American Historical Review, 116, no. 2 (April 2011): 335-51, at 335.

${ }^{49}$ Wilmslow Urban District Council Committee Minutes, 22 February 1915 and 29 March 1915, LUW/2472/3/4, CRO; "Frimley Council Meeting," Camberley News and Yorktown Observer, 5 June 1915, 3.

${ }^{50}$ Wilmslow Urban District Council Committee Minutes, 5 May 1916, LUW/2472/3/4, CRO.
} 
flow" and was very near capacity. After much negotiation, the War Office eventually agreed to part-subsidize improvements to the existing infrastructure. ${ }^{51}$

It was not just the altered "smellscapes" that appeared to threaten the existing landscape; with the opening of the internment camps, there were also increased levels of noise. Rural landscapes that had been accustomed to particular rhythms and sounds suddenly reverberated to the hustle and bustle of thousands of POWs. In Dorchester, where the camp abutted the town, the most perceptible noise came from the prisoners' own band. German sailors captured in the early naval skirmishes practiced their musical skills most afternoons. According to Bruno Schmidt-Reder, a German civilian in the camp, many of Dorchester's residents gathered to hear the music. "It was little wonder," he added, "as normally all that was to be heard in Dorchester was the bagpipes." However, not all locals were so enamored at the daily music. One contributor to the local newspaper was probably closer to the mark, when he complained that "many think [the instruments] ought to have been taken from them [the prisoners]." ${ }^{, 52}$

Developing and then maintaining the camps also generated new and more intrusive sounds. One of the main culprits in this respect was traffic noise. A steady stream of motor vehicles trundled to and from the three sites, bringing supplies, visitors, and guards. This "extraordinary traffic" was so intensive that it damaged the roads leading to both the Dorchester and Frith Hill camps. The members of Frimley Urban District Council saw a ready solution in their midst and proposed using POWs to conduct the necessary repairs. In Handforth, where similar problems occurred, it was ironically the military authorities that made the loudest

\footnotetext{
${ }^{51}$ Dorchester Borough Council Minutes, 26 May 1915, 14 March 1916, DC/DOB, Dorset History Centre (henceforth DHC).

${ }^{52}$ Schmidt-Reder, Kriegsgefangen!, 112-3; “The Prisoners of War,” Dorset County Chronicle, 27 August 1914, 6.
} 
complaints, repeatedly demanding that the local council make the roads to the camp more suitable for vehicular traffic. ${ }^{53}$

\section{III - Foreign Soil}

Waste disposal was just one of the many movements between the internment camp and the outside world. For the local population, the most frequent flow was that of people. The prisoner population itself was never stable. The Frith Hill camp with its cold tented accommodation closed for the winter months, during which time the internees were distributed to other camps, before returning in the spring. Handforth, meanwhile, was affected by the British authorities' decision, taken in the wake of the Lusitania sinking, to intern all male German civilians. After May 1915, the camp's civilian prisoners were gradually moved to the large Knockaloe internment camp on the Isle of Man. Maurice Jeger, an Austrian civilian, recalled being marched with some 250 other men up the one-kilometer hill to the railway station and then departing Handforth for good. ${ }^{54}$ In their place, German military prisoners were brought in, but even then the population was far from stable. The British frequently rotated the POWs; some men were sent to working camps, while others were transferred to different internment sites. The boundaries of internment, therefore, were never fixed, with constant comings and goings to the camps.

Once free of the physical constraints of captivity, the prisoners were not afraid to make their presence felt. When they had first arrived in Dorchester, Frith Hill, and Handforth, the captives had presented a rather bedraggled group. Exhausted by long journeys and cowed by unfamiliar surroundings, most had marched silently and sullenly from the stations to the camps.

\footnotetext{
${ }^{53}$ Dorchester Borough Council Minutes, 6 February 1915, DC/DOB, DHC; "Frimley Council Meeting," Camberley News and Yorktown Observer, 10 October 1914, 3; Handforth Urban District Council Committee Minutes, 7 October 1915, 3 May 1917, 5 July 1917 and 2 May 1918, LUHd/1/2, CRO.

${ }^{54}$ Maurice Jeger, 22 Monate in Englischer Kriegsgefangenenschaft. Aus den Internierungs-Lagern: Shrewsbury, Handforth, Knockaloe, Douglas (Insel Man) (Vienna, 1917), 34.
} 
However, as they settled into the fixed routines of life behind wire, the prisoners gradually became more accustomed to their new surroundings. Schmidt-Reder had first arrived in Dorchester "soaked through and freezing." For him, "these first hours in the camp were horrid." But as the weeks passed, he began to appreciate the Dorset countryside. Not only was the landscape around the camp "delightful," but the views were "green" and the sunsets "simply lovely." 55 With increased familiarity came greater confidence. No longer were the POWs content to watch on, as the locals jeered them on the streets or gawped through the camp fences; instead, they were confident enough to claim their own place within the local landscapes.

The prisoners' first real opportunity to sample the world beyond the wire came when some of them were briefly allowed out to buy supplies. Rather than being a state policy, the decision appears to have been made locally by the camp commanders on the ground. In Handforth, Jeger was permitted to stroll to the nearby town of Wilmslow, when his British born son came to visit. ${ }^{56}$ The situation was very similar in Dorchester, where the camp commandant allowed several German officers to go "shopping" in the town. However, when news of this arrangement seeped out, not everyone was so enthralled. One person complained about the "monstrous" situation, which had allowed Germans to "roam freely" even if they were "spending a lot of money in the town." Another local resident confirmed that he had already seen "three lots" out and about in Dorchester. ${ }^{57}$

If the sight of individual prisoners strolling around local towns caused considerable disquiet, then a decision to allow larger groups of Germans and Austrians to leave the internment camps was always destined to unsettle British residents still further. In Handforth, the camp commandant introduced a scheme to allow prisoners "on every fine day" to "march

\footnotetext{
${ }^{55}$ Schmidt-Reder, Kriegsgefangen!, 36, 64.

56 Jeger, 22 Monate, 28.

57 "War Notes," Western Gazette, 4 September 1914, 3; "Letters to the Editor," The Globe, 11 September 1914, 6; "Letters to the Editor," The Globe, 18 September 1914, 3.
} 
for an hour" around the surrounding countryside. There was only limited space to circulate within the camp itself, so this was a chance for the internees to stretch their legs properly. ${ }^{58}$ The same privilege was extended to the prisoners in Dorchester. As the recreation facilities in the camp were also limited, 200-300 of the internees were "allowed out for marches of 2 hours at a time under escort." 59

Although these marches were supposed to be an opportunity for the internees to take some exercise, the POWs also used the occasion to discover more of the landscape that surrounded their places of interment. "The lovely open countryside," as Gustav Plüschow, a captured German officer, described Dorset, no longer seemed so threatening once they were free to soak in the environment with their fellow prisoners. Increasingly confident of their surroundings, the prisoner marches were often a tuneful affair. In both Dorchester and Handforth, the men - all dressed in uniform - marched along singing German military songs, including the popular, nationalist song "The Watch on the Rhine" (Die Wacht am Rhein). ${ }^{60}$ When the large groups of soldiers reached urban streets, Plüschow remarked, they consciously sang their songs with "particular force and ecstasy," almost as if they were the "victorious troops" marching in under "General von Kluck."61

Any local who encountered the group would have come face to face with a large mass of enemy soldiers singing in German. The British who had once stared menacingly at their imprisoned foe now found that it was not them, but the Germans who seemed most comfortable in the wider environment. Understandably, this shifting relationship caused considerable consternation among many local people. Their fear was that the landscape that they knew so well was being disturbed by an intruding, enemy population. In Handforth, it fell to Samuel

\footnotetext{
${ }^{58}$ American Special Attaché, London, 11 April 1916, R901/83075, Bundesarchiv, Berlin (henceforth BArch Berlin).

${ }^{59}$ Robert Cecil, 'Note of Visit to Prisoners' Camps," 2 February 1915, FO383/106, TNA.

${ }^{60}$ Gustav Plüschow, My Escape from Donnington Hall (London, 1922), 166; "Handforth Prisoners in 'Clover'," The Alderley and Wilmslow Advertiser, 6 February 1915, 6.

${ }^{61}$ Plüschow, Escape, 167.
} 
Stockton, vicar of St Chad's parish church, to lead the fight back. Stockton deemed the German walks "so serious" that he used part of his Sunday sermon to address the matter and also started a petition to oppose them. The main criticism of Stockton and other locals was that the POWs behavior was "objectionable" and that it was "not pleasant" for "women and children" to be on the street at the same time as Germans. With Stockton's complaints coming amidst the violent protests surrounding the Lusitania sinking during which German-owned businesses in parts of the country were ransacked and looted, the camp commandant was forced briefly to halt the walks for the prisoners' own safety. ${ }^{62}$

Local residents could at least comfort themselves with the thought that the POWs' marches were going to be a temporary affair. As soon as the conflict was over, then the men would leave. The civilian and military prisoners, of course, were also desperate to end their period of internment and to return home to their friends, families, and old lives. While most eventually made it home, a large group of prisoners who died in captivity were destined never to leave Britain. The majority of these deaths were from ill health or disease; the influenza epidemic of 1918 proved particularly devastating. In addition, British sentries shot and killed two captured German soldiers: Wilhelm Schmidt and Franz Radojewski. Schmidt was "accidently" killed in Handforth in a dispute over cigarettes, while Radojewski was shot in May 1919 trying to cut through the wire fence that surrounded the Dorchester camp. ${ }^{63}$

Schmidt, Radojewski and the other prisoners who died in the camps were all laid to rest in the nearest cemeteries. The dead from Handforth were buried in Wilmslow Cemetery, which lay a little over two kilometers from the camp gates. Fordington Cemetery, which took those who had died in the Dorchester camp, lay at the other side of the town from the camp, while

\footnotetext{
62 "Handforth Villagers' Protest," Nottingham Evening Post, 20 May 1915, 3; Jeger, 22 Monate, 26.

63 "German Prisoner Shot," Liverpool Daily Post, 8 August 1918, 3; "Prisoner of War Fatally Shot," Dorset County Chronicle, 22 May 1919, 2. The worst incident occurred in November 1914 in Douglas on the Isle of Man, when guards shot and killed five prisoners during a disturbance: Panayi, Prisoners, 156-7.
} 
Frith Hill's dead were laid to rest in the nearby Deepcut Cemetery. In all three cases, funerals for the deceased provided the other prisoners of war with an opportunity to escape briefly the confines of the camps. As with the much-contested countryside walks, attending funerals also brought the internees and their captors together in one shared local landscape.

Burying the war dead in Britain was always a matter of last resort for the prisoners. As far as they were concerned, the dead should have been laid to rest in their own "homeland" (Heimat), close to their loved ones, rather than in "foreign soil." ${ }^{64}$ With no possibility to return the dead to Germany, the POWs instead attempted to personalize the actual burials. They were helped in this process by the fact that the British military authorities generally allowed the prisoners an "elaborate funeral" so long as it was done "at their own expense." 65 In reconfiguring the British landscape to make it more in keeping with Germany, the performative aspects of the funeral took center stage. POW camps have long been recognized as hotbeds of theatrical activity, but in this instance the performers took to the streets. ${ }^{66}$

Before a burial could commence, prayer services were normally held within the affected camp. Thereafter, the camp commandants allowed a selection of prisoners to form a cortege to accompany the coffin to the cemetery. In Frith Hill, only 16 POWs processed, while in Handforth some funerals saw up to 200 German prisoners following the coffin. ${ }^{67}$ On the slow walk from the Handforth and Dorchester camps to the cemeteries, the funeral corteges passed right through the center of the two towns. Local people who came out to view proceedings would have been greeted with the sight of a uniformed mass of enemy soldiers marching slowly behind the biers. The Imperial German flag, which was almost always draped over the deceased's coffin, helped the prisoners to impose their own national identity onto proceedings.

\footnotetext{
${ }^{64}$ L. Bogenstätter and H. Zimmermann, Die Welt hinter Stacheldraht: Eine Kronik des englischen Kriegsgefangenlagers Handforth bei Manchester (Munich, 1921), 83.

${ }^{65}$ War Office, "Report on the Directorate of Prisoners of War," September 1920, 24, FO369/1450, TNA.

${ }^{66}$ Hermann Pörzgen, Theater ohne Frau: Das Bühnenleben der Kriegsgefangenen Deutschen, 1914-1920 (Berlin, 1933); Rachamimov, "Disruptive Comforts"; Feltman, Stigma, 127-33.

67 "Funeral of German Prisoner," Surrey Advertiser, 12 September 1914, 7.
} 
In Handforth, funerals were awarded even more symbolism as the prisoners' own band also accompanied the procession through the streets and once in the cemetery, readings and music in German accompanied the deceased to the grave. ${ }^{68}$

The local population often viewed these elaborate German funerals with suspicion. In Dorchester, one onlooker observed skeptically that she hoped that in Germany "they pay as much respect to those [British prisoners] who die." 69 The funerals may well have met with local displeasure, but the only thing that the residents could really do was to restrict the visibility of the final graves. As was standard British practice for POW burials, a simple wooden cross was all that initially marked the burial plots. Any attempts to erect more permanent memorial structures generally met with "much local opposition."70 In Handforth, the local parish priest went a stage further and banned any tributes from the German prisoners' graves. "So long as I'm in charge," he is alleged to have said, "nothing is going to be placed on a Hun's grave."71 The location of the three camps on the edge of small urban areas forced the British and Germans to recognize the other. Yet at the same time, shared spaces, whether the streets or the cemeteries, also became points of conflict, particularly as the German prisoners started to become more at ease in the existing landscape.

\section{IV - Landscapes of Work}

Tensions between the local British population and the German POWs reduced in intensity as the internment camps started to become more established. Not only did the shock of the enemy's presence start to fade, but at the same time improvements to the infrastructure of the camps also eased complaints. In Handforth, for example, the military authorities finally

\footnotetext{
${ }^{68}$ Bogenstätter and Zimmermann, Stacheldraht, 83-5.

69 "Military Funeral of German Prisoner of War," Dorset County Chronicle, 2 September 1915, 5.

${ }^{70}$ War Office to Under Secretary of State for Foreign Affairs, 1 June 1916, FO383/122, TNA; War Office,

"Report on the Directorate of Prisoners of War," September 1920, FO369/1450, TNA.

${ }^{71}$ Bogenstätter and Zimmermann, Stacheldraht, 85.
} 
commissioned their own sewage system in early 1916. These changes, which even met with the American attaché's approval, eradicated the foul smells hanging over the village and assuaged local residents' complaints as a result. ${ }^{72}$ A lessening of tensions, however, did not just occur after German incursions into the environment had been curbed; relations ironically also improved when the POWs were given more, not less, opportunity to roam through the landscape. During the latter half of the war, the POWs were used increasingly to harvest crops, plough fields and to drain rivers. The local population generally accepted this work on the land, as the British, rather than the Germans, outlined the parameters of these incursions into the countryside.

For the first two years of Britain's internment policy, POWs were given very few opportunities to work. The public, as the head of the Directorate of Prisoners of War later acknowledged, initially refused to tolerate the employment of prisoners." ${ }^{, 73}$ If men worked at all, then it tended to be solely within the confines of the camps, where they performed their own trades. German journalists produced the camp newspaper, hairdressers offered a barber's service, and trained dentists filled the prisoners' cavities. With labor shortages in Britain increasing through late 1915, the inactivity of the POWs became all the more noticeable. Lord Newton, the Paymaster-General, was not alone in asking the pertinent question: "why not use Germans on our farms?" Newton's plea, along with calls from other landowners and politicians, gained traction through 1916 after the introduction of conscription had further reduced the availability of workers. From 1917 onwards, ever increasing numbers of POWs were deployed in Britain's industrial and agricultural sectors so that by the time of the armistice some 64,250 prisoners were in work. ${ }^{74}$

\footnotetext{
${ }^{72}$ American Special Attaché, London, 28 August 1916, R901/83075, BArch Berlin.

${ }^{73}$ War Office, "Report on the Directorate of Prisoners of War," September 1920, 50, FO369/1450, TNA.

74 "Why not use Germans on our Farms?," Manchester Courier and Lancashire General Advertiser, 21

December 1915, 5; Panayi, Prisoners, 206.
} 
Although the government accepted the need for POW labor, many locals living near the camps remained skeptical, fearing that the Germans would use the opportunity either to escape or to sabotage the local environment. In Handforth, rumors spread that prisoners employed on farms "gouge out the eyes" of potatoes before sowing them. Lieutenant Colonel Dauncey, the camp commandant, quickly scotched these allegations, pointing out in no uncertain terms that any farmer not to notice such acts of sabotage would have to be "blind or an idiot." ${ }^{" 75}$ Similar tales of German treachery spread in Dorchester too. After a contingent of German prisoners had been employed to tend the town's main park, people started to complain that they had planted geraniums to replicate the design of an Iron Cross. On closer inspection, the Town Council discovered that it was in fact a Maltese Cross that had formed part of the flowerbeds for the past 15 years. ${ }^{76}$

However, the more time the prisoners spent working, the more comfortable local people became with the basic principle that Germans might be allowed out of the camps. In Surrey, Frith Hill camp was re-sited to allow the prisoners to work on the construction of a new railway line, while Dorset County Council frequently included POW labor in its plans for gravel quarrying and road repairs. ${ }^{77}$ Further north in Cheshire, many of the farmers employing POWs quickly warmed to their new workers. One farmer even asked to be given more prisoners as they were cheap to employ, while another was so desperate for labor that he volunteered to billet five Germans in his own home. ${ }^{78}$ By 1918 , the prisoner labor system had become so firmly established that the farms surrounding the Handforth camp received a quota of POWs each day; camp guards distributed them almost "like postmen dropping letters."79

\footnotetext{
75 "German Prisoners of War," The Alderley and Wilmslow Advertiser, 11 May 1917, 2.

76 “Amusing 'Mare's Nest' at Dorchester," Western Daily Press, 10 October 1917, 4; Dorchester Borough Council Minutes, 25 October 1917, DC/DOB, DHC.

${ }^{77}$ Report of the American Special Attaché, 12 September 1916, FO383/164, TNA; Dorset County Council Minutes, 1 August 1916, DCC/A1/3/35, DHC.

${ }^{78}$ Cheshire War Agricultural Committee, 30 April 1918; Douglas Wright, 16 August 1918, DLT 4996/19/12, CRO.

79 “German Prisoners on Cheshire Farms," The Times, 29 August 1918, 4.
} 
The POWs, though, were not just employed to maintain the existing landscape, the British also used them to create entirely new landscapes. The Cheshire War Agricultural Committee was most active in this regard. It recognized early on that underutilized land in the county could be developed for food production. In both Germany and Britain, the First World War gave a fillip to longstanding human attempts to control nature, by making it more productive. ${ }^{80}$ As in other areas of Britain, the Committee had to draw on POW labor to complete this enormous task. From 1917, the Committee used POWs to clear overgrown watercourse. First to be cleared were the Rivers Gowy, Fender, and Arrowe, but the greatest achievement occurred on the Wirral peninsular where 250 prisoners "thoroughly cleansed and scoured out" the River Birkett. This brought 5,000 acres of low-lying land back into cultivation. $^{81}$ While the British expressed immense satisfaction at these environmental improvements, it is less clear what the German POWs gained from their efforts. Reflecting a popular medical discourse on healthy landscapes, the Committee could only suggest that the prisoners would get bigger muscles and better health. ${ }^{82}$

Using POWs to clear Cheshire's rivers only whetted the Committee's appetite. With an ever-growing prisoner population at its disposal and continual demands to increase food production, the Committee pushed forward ever-grander schemes of environmental reconfiguration. Its most ambitious plan was surely on the Frodsham marshes to the east of Chester. This vast area of low-lying land, which borders the estuary of the River Mersey, had once been a tidal salt plain until the construction of the Manchester Ship Canal in the late nineteenth century had severed the marshes from the sea. The Committee's grand plans

\footnotetext{
${ }^{80}$ David Blackbourn, The Conquest of Nature: Water, Landscape and the Making of Modern Germany (London, 2007), 4.

${ }^{81}$ County War Agricultural Committee, "Review of Work of above Committee from Date of Appointment to $30^{\text {th }}$ June 1918," CC1/4/1/1/1, CRO.

82 "Wirral War Agricultural Committee," Chester Chronicle, 10 November 1917, 5.
} 
involved German POWs draining some 3,000 acres of waterlogged land, thereby transforming the marshes into "one of the best crop producing areas anywhere." 83

At its 1918 peak, some 200 POWs at a time worked on the marshland drainage scheme. Laboring for an average of nine hours per day Monday to Friday and five hours on Saturdays, the prisoners systematically cleaned out old drainage ditches and, where needed, cut new ones. For an area where the weather was "nearly almost vile," as one Swiss inspector put it, the working conditions were clearly challenging. Some of the men had to spend their days wearing rubber boots, waist deep in cold water. ${ }^{84}$ Despite these efforts, the Cheshire War Agricultural Committee still found reason to bemoan the speed of progress. Instead of clearing 200 yards of land a day, it was suggested that the prisoners should be aiming for at least one mile. One member of the committee called for an inspector to be appointed to "ginger up" the POWs. ${ }^{85}$

There can be no denying that considerable tensions between the British and Germans remained. Indeed, in September 1918, the POWs working on Frodsham marsh briefly laid down their tools in protest at the poor conditions. As had been the case at Frith Hill, the tented accommodation, which did not "offer sufficient protection in rainy weather" proved to be a particular source of complaint. ${ }^{86}$ Yet, such incidents were still relatively minor compared to earlier disputes over the streets, sewage and noise. In all camps, relations tended to improve the longer the war went on and familiarity grew. ${ }^{87}$ Just as important in this process, however, was the fact that the prisoners appeared to be cultivating the local landscape. Gone was the sense that the landscape was somehow under attack from enemy outsiders; instead local people

\footnotetext{
${ }^{83}$ W. Carr and W. Mercer, "Reclamation of Frodsham Marshes," Journal of the Royal Agricultural Society, 108 (1947): 112-26, at 112; "War Agricultural Matters," Chester Chronicle, 26 May 1917, 6.

${ }^{84}$ Swiss Legation to Swiss Minister London, 23 June 1919, R901/83121, BArch Berlin.

85 "The Chronicle," Chester Chronicle, 17 August 1918, 4.

${ }^{86}$ Swiss Legation to Swiss Minister London, 10 September 1918, R901/83121, BArch Berlin; "German Prisoners at Frodsham," Chester Chronicle, 14 September 1918, 4. On Frith Hill complaints, see: Walter Page to Viscount Grey, 31 October 1916, FO383/164, TNA.

${ }^{87}$ Hinz, Kriegsgefangenschaft, 193-7.
} 
were able to comfort themselves with the thought that the Germans were shaping their environment according to a British template. ${ }^{88}$

\section{V - A Fading Presence}

When the armistice was signed on 11 November 1918 and the fighting finally came to an end, little immediately changed for the thousands of enemy prisoners interned in Britain. By May 1919, some 31,000 had returned, but this represented only one quarter of those held. ${ }^{89}$ The reason for the slow pace of returns lay with the British government's decision to follow France's lead and to hold its prisoners until the formal signing of a peace treaty with defeated Germany. ${ }^{90}$ As a result, daily life for the POW s continued as before, with Germans still clearing Frodsham marshes and working on farms in Cheshire and in Dorset. This period of waiting proved incredibly frustrating for the prisoners, who, as a Swiss report noted, had only "one desire which [was] to be sent home." 91 It was not until the end of 1919 that the British finally started to empty the remaining camps. In mid-November, the camp guards in Handforth led the prisoners back to the town's railway station, marching along the same streets that had been the scene of such tensions during the early years of the war. Trains then took the men to one of Britain's east coast ports, from where the POWs were loaded onto ships bound for the Netherlands and then to home. ${ }^{92}$

At the very moment that the authorities emptied Handforth and the other camps of their prisoner populations, the British staged their very first set of Armistice Day commemorations. In London, and across the country, when the clocks struck 11 a.m., people stopped what they

\footnotetext{
${ }^{88}$ For a similar history, albeit in Canada, see: Bohdan Kordan, No Free Man: Canada, the Great War, and the Enemy Alien Experience (Montreal, 2016).

${ }^{89}$ Panayi, Prisoners, 276.

${ }^{90}$ Reinhard Nachtigal, "The Repatriation and Reception of Returning Prisoners of War, 1918-22," Immigrants \& Minorities, 26, no. 1/2 (March/July 2008): 157-84, at 175.

${ }^{91}$ Swiss Legation to Swiss Minister London, 19 March 1919, FO383/506, TNA.

${ }^{92}$ Feltman, Stigma, 162; “ “Jerry's' Farewell,” The Alderley and Wilmslow Advertiser, 14 November 1919, 4.
} 
were doing to observe two minutes' silence in memory of the war dead. ${ }^{93}$ Scenes of sorrow and careful reflection occurred across Cheshire, Surrey, and Dorset too. The two minutes' silence in Dorchester was apparently a "beautiful and touching observance," while in Wilmslow and Handforth "not a sound was heard." 94 With Armistice Day coinciding with the final departure of the POWs, this appeared to mark a fresh start; the people of Handforth, Frimley, and Dorchester could finally draw a line under the difficult internment episode. The landscapes that had first been militarized and then shared with the enemy could be returned to the local community, thereby masking the "reality of war." $" 95$ In short, the closure of the camps allowed local people to create a new, more "normal" past for their communities.

At the war's end, it was not just the military prisoners who departed Britain for good; the conflict also ushered in the demise of the country's previously deep-rooted Anglo-German community. Those people who had not been deported to Germany understandably had little wish to remain in Britain. ${ }^{96}$ With both military and civilian prisoners largely gone, there was no longer a German community within Britain in a position to remember the camps. ${ }^{97}$ Yet, this episode was not entirely forgotten. In Germany, groups of former POWs fostered their own memory culture for Handforth, Frith Hill, Dorchester, and the other camps. Members of the Reich Association of Former Prisoners of War (Reichsvereinigung ehemaliger Kriegsgefangener, REK), the largest of these organizations, met regularly for welfare, friendship and to record the history of internment. ${ }^{98}$ In 1921, for example, two former Handforth prisoners, Ludwig Bogenstätter and Heinrich Zimmermann, published their own

\footnotetext{
93 Adrian Gregory, The Silence of Memory: Armistice Day 1919-1946 (Oxford, 1994), 9-13.

94 “Local \& District News," Western Gazette, 14 November 1919, 3; "Local Notes," The Alderley and Wilmslow Advertiser, 14 November 1919, 4.

${ }^{95}$ George Mosse, Fallen Soldiers: Reshaping the Memory of the World Wars (Oxford, 1990), 107.

${ }^{96}$ See in particular: Panikos Panayi, The Enemy in our Midst: Germans in Britain during the First World War (Oxford, 1991), 283.

${ }^{97}$ The only internees to remain were those deemed to sick to travel. Ivan B., for example, remained in the "Cheshire County Asylum" until he died aged 70 in 1949: Parkside Asylum, Notice of Death, NHM 8/5176/65 CRO.

${ }^{98}$ On the REK, see: Feltman, Stigma, 176-91.
} 
history of the camp. The REK enthusiastically called it "by far the best portrayal of life in an English camp." Reflecting the continuation of the camp communities within Germany, the two authors promised to donate all profits from the book to the relatives of those who had died in Handforth. ${ }^{99}$

After the war, a memory culture for the camps had all but moved to Germany. Within Britain, only traces of this complex wartime story remained. The most visible reminder that thousands of prisoners had once lived in the country were the graves of the war dead. The bodies of 19 prisoners lay in Wilmslow Cemetery; 48 POWs were buried in Dorchester, and three near Frimley. Other former prisoners from the three camps had been interred near hospitals, asylums and labor camps, where the individuals had died. During the war years, these "enemy" graves had been tolerated at best; after the war very little changed. When the Handforth camp finally closed in November 1919, the commandant left money with the cemetery authorities in Wilmslow for the maintenance of the POW burial plots. In the early 1920s, a small memorial stone was erected in the cemetery listing the men's names under the words: "Ruhestätte: Kriegsgefangener Deutscher" (Final Resting Place of German Prisoners of War). In Dorchester, a similar memorial, complete with the relief of a kneeling soldier and German inscription, was placed in the cemetery during the camp's final months. ${ }^{100}$

Besides these physical remains hidden away in quiet cemeteries, there was little else to remind local people of the internment camps. The Frith Hill camp, which had only ever been a tent encampment, was easily cleared. In Dorchester, the Ministry of Munitions auctioned off the main assets of the POW camp; the brick buildings that remained were given over to the Territorial Army. ${ }^{101}$ In Cheshire, meanwhile, the authorities returned the Handforth camp back

\footnotetext{
99 Bogenstätter and Zimmermann, Stacheldraht; “Aus der Welt der Bücher,” Der Heimkehrer, 15 August 1921, 4. For Dorchester, see: “Ehemalige Angehörige des Lagers Dorchester!,” Der Heimkehrer, 1 February 1921, 4. ${ }^{100}$ Wilmslow Cemetery Register, 27 October 1919, LUW17 CRO; Josef Jakob Melzl, "Bilder aus dem 'p.o.w. camp' Dorchester" (London, 1919). 101 “Sales by Auction,” Western Gazette, 6 August 1920, 1; Map, "Dorchester RHA Barracks,” 1925, WO78/3052, TNA.
} 
to its original owners, the Bradford Dyers Association, but as had been the case before the war, the Association could find no use for the factory. ${ }^{102}$ Although unacknowledged locally, the POWs also left small traces on the landscapes surrounding the camps. Their hours of hard toil on the Frodsham marshes, for example, had left sustainable grazing pastures. And in Handforth too, some parts of a previously militarized landscape also found an afterlife. The camp's modern sewage facilities, which both the Handforth and Wilmslow Urban District Councils desired, were eventually integrated into Wilmslow's system. ${ }^{103}$ Yet in both cases, the role that the POWs had played in shaping these environmental changes was left unsaid.

With very few traces of the internment regimes remaining, local people could instead turn to commemorating their own war dead. War memorials and remembrance rituals, of course, had a crucial function for the bereaved, as the survivors tried to come to terms with their wartime losses. ${ }^{104}$ But in the case of Dorchester, Handforth, and Frimley more generally, they also helped to normalize the regions' complex wartime history. The greater the focus on British victims of the conflict, the more invisible the German prisoners became. In 1922, the members of St Chad's parish church in Handforth placed a wooden memorial plaque on the church walls. Even though small groups of POWs had worshiped on occasion in the church, the simple plaque contained only the names of 24 British soldiers killed in the war. ${ }^{105}$ The same was true of Frimley, where a brass memorial plaque for the community's own war dead was placed in St Peter's church in 1920, and in Dorchester, which received its own cenotaph in 1921. As annual rituals of remembrance at these sites of memory became more established, the presence of the POWs faded. Only in Dorchester, where groups of Scouts occasionally laid a

\footnotetext{
${ }^{102}$ For the pre-war abandonment of the site, see: "Derelict Factory's Future," Manchester Courier and Lancashire General Advertiser, 19 March 1914, 12. On the Bradford Dyers Association's inter-war links, see: Handforth Urban District Council to Ministry of Health, 7 December 1934, HLG 50/449, TNA. ${ }^{103}$ Handforth Urban District Council Committee Minutes, 5 January 1920, LUHd/1/2, CRO.

${ }^{104}$ On grief, see: Jay Winter, Sites of Memory, Sites of Mourning: the Great War in European Cultural History (Cambridge, 1995).

${ }^{105}$ Handforth Parish, Register of Services, 4 August 1918, P10/2/1, CRO.
} 
wreath on the German memorial in Fordington Cemetery, did some public recognition remain. ${ }^{106}$

The increasing invisibility of local internment histories was encouraged by the public's suspicions of POWs more generally. In Britain's “commemorative pecking order", former POWs, who had returned from German captivity, ranked fairly low. ${ }^{107}$ In stark contrast, the war dead, particularly those killed on the western front, were at the very centre of commemorative activity. The reason for the POWs low standing were manifold, but rested principally on a negative conception of their war experience. Whereas the conflict's frontline dead could easily be labelled as "heroic" victims, categorising the former POWs, who had survived the war, proved much trickier. As captured soldiers, their wartime service became something that they "lamented" and that the public also viewed "as lamentable."108 With even British POWs struggling to maintain a place in the country's memory culture, it is little wonder that the captured Germans found almost no place in local commemorative activity.

The outbreak of hostilities against Nazi Germany in 1939 encouraged a further reframing of Britain's First World War narratives. Fighting the brutal Nazi regime reinvigorated the remembrance of the earlier conflict, as the dead from two World Wars were placed together on memorials and in rituals of remembrance. ${ }^{109}$ For Handforth, Frimley and Dorchester, the Second World War also provided a further opportunity to move beyond the earlier experience of internment. In Handforth, the disused factory buildings were brought back to life not to house German prisoners, but to form part of a larger Royal Air Force (RAF) complex. Rather than stories of marching POWs, camp diseases, and deaths, the "friendly" sight of British tanks, RAF personnel and military aircraft now provided the wartime backdrop.

\footnotetext{
106 "Dorchester Scoutmaster and the 'Chief'," Western Gazette, 13 June 1930, 2.

${ }^{107}$ Alon Rachamimov, POWs and the Great War: Captivity on the Eastern Front (Oxford, 2002), 221-8.

108 Oliver Wilkinson, “A Fate Worse than Death? Lamenting First World War Captivity," Journal of War \& Culture Studies, 8, no. 1 (2015): 24-40, at 25; Jones, Violence, 319-26.

${ }^{109}$ Dan Todman, The Great War: Myth and Memory (London, 2007), 94-5.
} 
Further south, Frimley and Dorchester also gained a new role in the Second World War. Land around the former provided accommodation for troops fighting in Europe, while in Dorchester the land on which the former internment camp had stood was turned into an infantry training center. ${ }^{110}$ The transposition of these sites into more familiar places helped them to blend unobtrusively into the landscape, in a way that was far more successful than had been the case in the earlier conflict. ${ }^{111}$

During the Second World War, the German POWs buried in British cemeteries were joined by British servicemen killed in the most recent conflict. 13 British servicemen were buried in Wilmslow, seven in Deepcut Cemetery near Frimley and two in Dorchester's Fordington Cemetery. These new graves, marked with the familiar Imperial War Grave Commission Portland stone steles, dominated the sites, relegating the older POW graves as a result. In the early 1960s, locals in the three towns finally gained full control of the cemeteries. Under an international agreement between Britain and the Federal Republic of Germany, the bodies of all German servicemen killed in the two World Wars, who had been buried in local British cemeteries, were to be brought together in one single site. ${ }^{112}$ A remote part of Cannock Chase in Staffordshire was chosen for this purpose. Between the signing of the agreement in 1959 and the dedication of the new cemetery in 1967, some 5,000 bodies, including the POWs from the Handforth, Frith Hill, and Dorchester camps, were exhumed and reinterred in Staffordshire. Each prisoner now received a uniform headstone, which the German War Graves Commission supplied. ${ }^{113}$

\footnotetext{
110 "Re World War I POW camp at Handforth,” Cheshire Ancestor, 46 (2015): 17; War Office, "Infantry Training Centre, Dorchester," 13 May 1940, WO 32/20939, TNA.

111 On the shifting meanings in buildings, see: William Whyte, "How do Buildings Mean? Some Issues of Interpretation in the History of Architecture," History and Theory, 45, no. 2 (2006): 153-77.

112 "Agreement between the Government of the United Kingdom of Great Britain and Northern Ireland and the Government of the Federal Republic of Germany regarding German War Graves in the United Kingdom," 16 October 1959, HO282/21, TNA.

113 "Feierstunde zur Einweihung des deutschen Soldatenfriedhofes Cannock Chase," 10 June 1967, C/C/PR/5/1/4, Staffordshire Record Office, Stafford.
} 
Once the bodies of the prisoners had been removed, only a few visible reminders of these towns' internment history remained. The prisoners' memorial in Dorchester still stood, even though it now looked over a series of empty burial plots. In Handforth, meanwhile, the Co-operative Wholesale Society took ownership of the former POW camp buildings in the early 1960s and utilized them as a warehouse facility. It was only in 1994 that the buildings were finally demolished, the land cleared and a housing development built in its place. The new family homes were built in the mock-Tudor style, which enjoyed something of a revival in the 1980s and 1990s. Half-timbered walls, fake leaded light windows and neat manicured front lawns filled the site. Fittingly, the architectural style of the new houses, set alongside the quiet waters of the River Dean, harked back to a rural, nostalgic past; the actual, far more complex history, of the site and of Britain's twentieth century vanished in the new, artificial landscape. ${ }^{114}$

\section{VI - Conclusion}

After Dorchester had bade farewell to the last of the internees, the Western Gazette declared the town to be "at last clear of German prisoners of war." For good measure, it added that nobody "would ever wish them back." ${ }^{115}$ Pleasure at the news of the camp's closure reflected the obvious relief that the war had finally ended with Britain victorious, but it also stemmed from the fact that a lost landscape could now be reclaimed. As soon as the camp had been cleared, local people took "full advantage" of ancient rights and started to stroll around the land that had long "been enclosed by barbed wire." 116 During the war, locals and the newly arrived prisoner population had reluctantly had to share the landscape in and around the camps. For

\footnotetext{
${ }^{114}$ Jerome de Groot, Consuming History: Historians and Heritage in Contemporary Popular Culture (New York, 2016), 146.

115 "Reparation of the German Prisoners," Western Gazette, 21 November 1919, 3.

116 “Departure of Prisoners of War," Dorset County Chronicle, 20 November 1919, 5.
} 
this reason, mutually competing claims to scarce resources, access to roads and basic sanitary facilities often turned the wider environment into an arena of bitter conflict. Contested places on the home front, whether in Dorchester, Frimley, Handforth or elsewhere, are crucial for interpreting not only the history of internment, but also for understanding the extent to which militarized landscapes spread at home during the First World War.

In the British case, the history of internment also helps to shine a critical light on the country's First World War memory culture. In Dorchester, Frimley, and Handforth, a desire to return local landscapes to their earlier configuration helped to ensure all evidence of the camps quickly faded. By the mid-1920s, the only significant signs of camp life were the prisoners' graves, but even these had been cleared by the 1960s. With the loss of physical remains, a crucial link locally between memory and place, which may have helped to keep this history visible, was broken. ${ }^{117}$ Nationally, there was also little incentive for the state to focus its attention on the wartime internment experience. At a time of considerable economic and social upheaval, as the country tried to move from a wartime to a peacetime state, the focus of national commemorative activity was understandably on the British war dead, rather than on the interned enemy. ${ }^{118}$ Solemn events, such as the two minutes' silence, helped to create a workable narrative of the conflict, while at the same time encouraging people to unite around the 'sacrifice' of those killed at the front. ${ }^{119}$ Locally and nationally, therefore, Britain's wartime internment camps quickly vanished from both the physical landscape and from the country's burgeoning memory culture.

\footnotetext{
${ }_{117}$ Pierre Nora, "Between Memory and History: Les Lieux de Mémoire," Representations, 26 (Spring 1989): 724 , at 22.

${ }^{118}$ On post-war discord, see: Jon Lawrence, "Forging a Peaceable Kingdom: War, Violence, and Fear of Brutalization in Post-First World War Britain," Journal of Modern History, 75, no. 3 (September 2003): 557-89; Panayi, Prisoners, 8-10.

${ }^{119}$ Bob Bushaway, "Name upon Name: The Great War and Remembrance," in Myths of the English, ed. Roy Porter (Cambridge, 1992), 136-61.
} 
In many respects, the dedication of Handforth's new war memorial in 2016 fits into this existing pattern of commemoration. Harking back to the architecture of the interwar years, the stone obelisk, with its embossed laurel wreath, espouses a narrative of gallant national sacrifice. Following its recent dedication, the structure serves as a focal point for wreath laying and remembrance services for the dead of the two World Wars. However, neither the memorial, nor the rituals of remembrance performed at the site, give any clues to the existence of the large POW camp that had once dominated Handforth. Buried mnemonically by a war memorial, the history of the camp and the POWs who died in it have been completely silenced. The commemorative process in Handforth bespeaks a wider failure to integrate the history of internment into Britain's local and national memory culture. Despite state and public engagement in the First World War centenary, tales of personal tragedy, wartime poetry, and rituals of remembrance still take precedent over a more complex wartime past that included both civilian and military internment. ${ }^{120}$

${ }^{120}$ David Reynolds, "Britain, the Two World Wars, and the Problem of Narrative," The Historical Journal, 60, no. 1 (March 2017): 197-231, at 226; David Reynolds, The Long Shadow: The Great War and the Twentieth Century (London, 2013), 387. 